\title{
Modelling the distribution of Amazonian tree species in response to long-term climate change during the mid-late Holocene
}

Article

Accepted Version

Gomes, V. H. F., Mayle, F. E., Gosling, W. D., Vieira, I. C. G., Salomão, R. P. and ter Steege, H. (2020) Modelling the distribution of Amazonian tree species in response to longterm climate change during the mid-late Holocene. Journal of Biogeography, 47 (7). pp. 1530-1540. ISSN 1365-2699 doi: https://doi.org/10.1111/jbi.13833 Available at https://centaur.reading.ac.uk/89903/

It is advisable to refer to the publisher's version if you intend to cite from the work. See Guidance on citing.

Published version at: http://dx.doi.org/10.1111/jbi. 13833

To link to this article DOI: http://dx.doi.org/10.1111/jbi.13833

Publisher: Wiley

All outputs in CentAUR are protected by Intellectual Property Rights law, including copyright law. Copyright and IPR is retained by the creators or other copyright holders. Terms and conditions for use of this material are defined in the End User Agreement. 


\section{www.reading.ac.uk/centaur}

\section{CentAUR}

Central Archive at the University of Reading

Reading's research outputs online 


\section{Modeling the distribution of Amazonian tree species in response to long-term climate change during the Mid-Late Holocene}

Vitor H. F. Gomes ${ }^{1,2^{*}}$, Francis E. Mayle ${ }^{3}$, William D. Gosling ${ }^{4}$, Ima C. G. Vieira ${ }^{2,5}$, Rafael P. Salomão ${ }^{5,6}$, Hans ter Steege $e^{7,8}$

${ }^{1}$ Escola de Negócios Tecnologia e Inovação, Centro Universitário do Pará, Belém, Pará, Brazil ${ }^{2}$ Programa de Pós-Graduação em Ciência Ambientais, Universidade Federal do Pará, Belém, Pará, Brazil.

${ }^{3}$ Centre for Past Climate Change and Department of Geography \& Environmental Science, School of Archaeology, Geography and Environmental Science (SAGES), University of Reading, Reading, Berkshire, UK.

${ }^{4}$ Department of Ecosystem \& Landscape Dynamics, Institute for Biodiversity \& Ecosystem Dynamics, University of Amsterdam, Amsterdam, The Netherlands.

${ }^{5}$ Coordenação de Botânica, Museu Paraense Emílio Goeldi, Belém, Pará, Brazil.

${ }^{6}$ Programa Professor Visitante Nacional Sênior na Amazônia - CAPES, Universidade Federal Rural da Amazônia, Belém, Pará, Brazil.

${ }^{7}$ Naturalis Biodiversity Center, Leiden, The Netherlands.

${ }^{8}$ Systems Ecology, Vrije Universiteit, Amsterdam, The Netherlands.

\section{Correspondence}

Vitor H. F. Gomes, Escola de Negócios Tecnologia e Inovação, Centro Universitário do Pará, Av. Alcindo Cacela 1523, Belém, PA, 66040-020, Brazil.Email: vitor.gomes@prof.cesupa.br

\section{Funding information}

Coordenação de Aperfeiçoamento de Pessoal de Nível Superior, Grant/Award Number: 001; Conselho Nacional de Desenvolvimento Científico e Tecnológico, Grant/Award Number: 308778/2017-0 and 407232/2013-3

Handling Editor: Camila Ribas 


\section{ABSTRACT}

Aim: To 1) assess the environmental suitability for rainforest tree species of the families Moraceae and Urticaceae across Amazonia during the Mid-Late Holocene and 2) determine the extent to which their distributions increased in response to long-term climate change over this period.

Location: Amazonia.

Taxon: Tree species of Moraceae and Urticaceae.

Methods: We used MaxEnt (maximum entropy modelling) and inverse distance weighting (IDW) interpolation to produce environmental suitability and relative abundance models at 0.5 degree resolution for Moraceae and Urticaceae tree species, based on natural history collections and a large plot dataset. To test the responses of the Amazon rainforest to longterm climate change, we quantified the increase in environmental suitability and modelled species richness for both families since the Mid Holocene (past 6,000 years). To test the correlation between the relative abundance of these species in the modern vegetation versus modern pollen assemblages, we analysed the surface pollen spectra from 46 previously published paleoecological sites.

Results: We found that the mean environmental suitability, for the Amazon basin as a whole, for species of Moraceae and Urticaceae showed a slight increase (6.5\%) over the past 6,000 years, although southern ecotonal Amazonia and the Guiana Shield showed much higher increases (up to $68 \%$ ). The accompanied modelled mean species richness increased by as much as $120 \%$ throughout Amazonia. The mean relative abundance of Moraceae and Urticaceae correlated significantly with the modern pollen assemblages for these families $\left(R^{2}=52 \%\right)$. Main conclusions: Increasing precipitation between the Mid and Late Holocene expanded the range of suitable environmental conditions for Amazonian humid rainforest tree species in the Moraceae and Urticaceae families, thus leading to rainforest expansion in ecotonal areas of Amazonia, consistent with previously published fossil pollen data.

\section{KEYWORDS}

Amazonian rainforest, climate change, distribution modelling, Holocene, Moraceae, tree species, Urticaceae. 


\section{INTRODUCTION}

Amazonia has experienced marked changes in climatic conditions since the Last Glacial Maximum (LGM), around 21 kyr before present (BP) (Wang et al., 2017). Simulations and fossil pollen data suggest that Amazonia remained predominantly forested during the LGM, although savanna expanded at the expense of forest in ecotonal areas, especially in southern Amazonia (Mayle \& Beerling, 2004). The onset of the Holocene (ca. 12 kyr BP) was marked by rising temperatures and precipitation (Maslin \& Burns, 2000), but the Early-Mid Holocene (ca. 8-4 kyr BP) was characterized by significantly drier climatic conditions compared with present, with minimum precipitation centred around 6 kyr BP. The South American Summer Monsoon (SASM) subsequently strengthened during the late Holocene (ca. 3-4 ka BP), with increased precipitation facilitating the expansion of rainforest tree species (Vidotto et al., 2007). Studies using species distribution models (SDMs) have shown the climate-driven southward expansion of Amazonian tree species, and consequent contraction of Cerrado vegetation (woody savannas), during the late Holocene, attributed to both increased precipitation and temperature (Bueno et al., 2017). Ledo \& Colli (2017) showed that warmadapted tree species expanded along a southeastern - north-western corridor (encompassing Amazonian rainforest, Cerrado/Chiquitano dry forest, and Atlantic forest) during Mid-Late Holocene.

Fossil pollen records obtained from lake sediment cores demonstrate a long-term trend of climate-driven rainforest expansion in ecotonal areas of Amazonia, at the expense of semideciduous dry forests and Cerrado savannas (Reis et al., 2017). The strongest evidence for Late Holocene, climate-driven, southward rainforest expansion comes from fossil pollen data from two lakes - Laguna Bella Vista and Laguna Chaplin - in Noel Kempff Mercado National Park in ecotonal northeastern Bolivia (Mayle et al., 2000). At Laguna Bella Vista the abundance of Moraceae/Urticaceae pollen markedly increased between $2790 \mathrm{cal}$ yr and $1530 \mathrm{cal}$ yr BP. At Laguna Chaplin, $100 \mathrm{~km}$ further to the south, this forest expansion occurred later, between $2240 \mathrm{cal} y r$ and $660 \mathrm{cal}$ yr (Burbridge et al., 2004). The differing chronologies of rainforest expansion between these two lakes suggest a rainforest expansion rate of ca. $0.03 \mathrm{~km} / \mathrm{yr}$. Modern pollen rain studies (Gosling et al., 2005, 2009) demonstrate that $>40 \%$ abundance of Moraceae/Urticaceae pollen is indicative of humid evergreen rainforest, while presence of Curatella americana L. pollen is indicative of savanna, especially if accompanied by high (>40\%) grass (Poaceae) pollen percentages.

The modern pollen assemblages from the surface-sediment of both lakes reflect the closedcanopy humid evergreen rainforest surrounding them today, with $40-50 \%$ Moraceae/Urticaceae pollen (rainforest taxa) and $<10 \%$ Poaceae pollen. This contrasts with $<$ $20 \%$ Moraceae/Urticaceae and ca. 40\% Poaceae pollen during drier conditions of the MidHolocene, consistent with a mosaic of semi-deciduous dry forest and savanna, which dominates the Brazilian Cerrado biome south of Amazonia today (Mayle et al., 2007). The 
families Moraceae and Urticaceae are commonly found in Amazonian rainforests (ter Steege et al., 2015, 2006). Moraceae is among the 10 most abundant tree families in Amazonia contributing 11 of the 227 hyperdominant species ( $5 \%$ in total) and it is the most dominant tree family in Bolivian wet forests (ter Steege et al., 2015, 2013). Urticaceae encompasses many herbaceous species, but is mainly represented by species of the arboreal genera Cecropia and Pourouma (Appendix S3). The pollen of these two families is well-represented in Amazonian fossil records, but these families are difficult to distinguish palynologically and are thus typically recorded as Moraceae/Urticaceae pollen type (Burn \& Mayle, 2008). However, the Moraceae/Urticaceae pollen type is usually attributed to Moraceae rather than Urticaceae, because Moraceae is much more common than Urticaceae in inventories of vegetation plots (Burbridge et al., 2004; Mayle et al., 2000).

\subsection{Aims and Approach}

Although it is well established from the aforementioned fossil pollen records that Mid-Late Holocene climate change drove southward expansion of ecotonal rainforests by at least 130 $\mathrm{km}$ in southern Amazonia (Mayle et al., 2000), the paucity of fossil pollen records across the Amazon basin, coupled with the taxonomic limitations of pollen analysis (restricted to family level, or genus level at best), hampers understanding of species-level responses of rainforest taxa across the basin.

Here, we circumvent these spatial and taxonomic limitations of pollen analysis by employing a species distribution modelling approach to investigate how Mid-Late Holocene climate change increased the environmental suitability for Amazonian rainforest species within the Moraceae and Urticaceae families, and thereby assess the spatial scale of climate-driven species range distribution in Amazonia. We focus on the Moraceae and Urticaceae families because changing pollen abundance of these taxa in lake sediment records reliably reflect past changes in rainforest distribution (e.g. Mayle et al., 2000). Our approach entails modeling the environmental suitability of Moraceae and Urticaceae tree species using a conservative pipeline (Gomes et al., 2018), to define their estimated area of occupancy (AOO) (IUCN, 2017). We do this for current climate conditions and Mid-Holocene climate projections from seven global circulation models (GCMs) (Hijmans et al., 2005). We also compare the relative abundance of Moraceae and Urticaceae within lake surface-sediment pollen assemblages versus parent vegetation to verify that changing abundance of these taxa in the fossil pollen record is a reliable proxy for past changes in rainforest distribution.

\section{MATERIALS AND METHODS}

\subsection{Amazonian base map}

We based Amazonian lowland forest on ter Steege et al. (2015). The base map consists of 2,191 0.5-degree cells (Figure S1). We divided Amazonia into six regions following Quesada et al. (2011) and ter Steege et al. (2013), Guiana Shield (GS), north-western Amazonia (WAN), 
south-western Amazonia (WAS), southern Amazonia (SA), eastern Amazonia (EA) and central Amazonia (CA). This division is mainly based on the maximum geological age of the soils.

\subsection{Environmental suitability}

We estimated mean environmental suitability based on models of species potential distribution as predicted by MaxEnt version 3.3.3k (Steven J. Phillips et al., 2006). MaxEnt is one of the most commonly used methods for modelling species distributions. Its predictions are considered consistent in estimating local occurrence (Aguirre-Gutiérrez et al., 2013) and regularly competitive against the highest performing methods (Elith \& Graham, 2009). This machine-learning method is based on presence-only data which enable the use of the natural history collections available in herbaria and online databases and also release the user from problems related to unreliable absence records (Jiménez-Valverde et al., 2008). The collections of Moraceae and Urticaceae used by MaxEnt were downloaded from the Global Biodiversity Information Facility (GBIF, http://www.gbif.org/, January 2018), using the function 'gbif' from the R package 'dismo' (Hijmans et al., 2017), based on the most recent list of Amazonian tree species (ter Steege et al., 2019). We assigned all individuals to species level and intraspecific levels were ignored. All collections were checked for inconsistencies using a cleaning pipeline (Gomes et al., 2018) and all records were removed for those species which had: imprecise georeferences, duplicates at 0.5 degree spatial resolution, records assigned to capital cities or centroids of provinces, latitude equal to longitude and equal to exactly zero. We used collection data from the entire Neotropics to prevent SMDs deficiencies that are associated with models based on a species' partial geographic range (Raes, 2012). Species with a small number of records $(<6)$ were not used as they may develop inaccurate predictions (van Proosdij et al., 2015). We brought occurrences and environmental variables to the same resolution before modelling species potential distribution.

The environmental data used by MaxEnt were downloaded from WorldClim at 10 arc-minutes ( $\sim 18.6 \mathrm{~km}$ spatial resolution, for 19 environmental variables) (Hijmans et al., 2005). All environmental variables were cropped to the geographic extent of the Neotropics to avoid range contraction or underprediction related to modelling partial species distributions (Raes, 2012). We used the function 'aggregate' from the R package 'raster' (Hijmans, 2017) to aggregate all variables from 0.17 (10 arc-minutes) to 0.5 -degree $(\sim 50 \mathrm{~km})$ spatial resolution. We based the selection of the variables on their biological relevance and correlations, using the common Spearman's rank correlation coefficient threshold of $\mid$ rho $\mid>0.7$ to identify correlated variables (Figure S2) (Dormann et al., 2013). Since the seasonal climate produced by latitudinal shifts of the South American Summer Monsoon is the overriding control over the geographical limit of the Amazonian rainforest (Martin et al., 1997), we selected precipitation seasonality (BIO15). We also selected isothermality (BIO3), which measures the climate seasonality according the variation of day/night temperatures (O'Donnell \& Ignizio, 2012). Furthermore, we selected annual precipitation (BIO12) as the range limits of species are 
defined by their ability to endure dry conditions, where the threshold for the presence of the studied families is an annual precipitation of $\sim 1,500-2,000 \mathrm{~mm}$ (Esquivel-Muelbert et al., 2016). Finally, we followed Whitney et al. (2014) and selected the mean temperature of coldest quarter (BIO11) because of the importance of low temperature minima for the floristic composition of seasonally-dry tropical forest at the ecotonal boundaries of Amazonia.

We corrected the modelled potential distribution of the species for geographical sampling bias by having the background sample with the same bias as the presence data using a target-group background (Phillips \& Dudík, 2008). This correction improves model accuracy and greatly contributes to the analysis, given MaxEnt's assumption that species records are an independently drawn sample from the unknown probability distribution. To achieve that, we produced a background file based on a binary raster grid sampled from all Amazonian tree species records available on GBIF, reflecting local survey effort. In MaxEnt, we excluded product, threshold and hinge features due to their lack of biological justification with the environmental data used (Merow et al., 2013). The models were not iterated using subsets of presences.

The modelled potential distribution of the species was constrained to their extent of occurrence (EOO) (IUCN, 2017) by drawing a polygon around their presence records using a convex hull plus a buffer of $300 \mathrm{~km}$ (Syfert et al., 2014), resulting in the estimated areas of occupancy (AOOs) (IUCN, 2017). This is a conservative use of MaxEnt's predictions, limiting the modelled potential distribution within the range of species' known occurrences. It also adds a distribution area (buffer of $300 \mathrm{~km}$ ) including a spatial structure that preserves finer scale gradients (VanDerWal et al., 2009). A species' original AOO was based on current climate conditions (average for 1960-2000). A species' past AOO for Mid-Holocene (ca. 6,000 yr BP) was based on variables from seven IPPC5 global climate model (GCM) projections, BCC-CSM (Xiao-Ge et al., 2013), CCSM4 (Yeager et al., 2012), HadGEM2-ES (C. D. Jones et al., 2011), IPSLCM5A-LR (Swingedouw et al., 2013), MIROC-ESM (Watanabe et al., 2011), MPI-ESM-LR (Giorgetta et al., 2013) and MRI-CGCM3 (Tatebe et al., 2012). Although predicting past climatic conditions of Amazonia may be problematic, since Global climate models (GCMs) may diverge in modelling some parts of the Amazonian basin (Smith et al., 2018), we minimized such divergences by averaging several GCMs from CMIP5.

\subsection{Species relative abundance}

We obtained abundance data of Moraceae and Urticaceae from the Amazon Tree Diversity Network (ATDN, http://atdn.myspecies.info/) and modelled the relative abundance of the two families spatially. Abundance maps were constructed using 1912 1-ha tree inventory plots distributed across Amazonian rainforest (Amazon basin and the Guyana Shield), recording all individuals with $\geq 10 \mathrm{~cm}$ diameter at breast height (dbh) (ter Steege et al., 2015). We used inverse distance weighting (IDW) interpolation to produce relative abundance maps from the 
plot abundance data. We defined the relative abundance (RA) for each cell as $R A_{i}=n_{i} / N$, where: $\mathrm{n}_{\mathrm{i}}=$ the number of individuals of taxon $\mathrm{I}$, and $\mathrm{N}=$ the total number of trees. IDW models were based on the nearest 150 plots within a $300 \mathrm{~km}$ distance limit (Gomes et al., 2018; ter Steege et al., 2015). The plot weights were calculated by taking the square root of the distance in degrees.

\subsection{Pollen data}

We analyzed pollen records from 46 Amazonian paleoecological sites available in palynological studies to obtain the percentage of Moraceae and Urticaceae pollen in the sediment core assemblages (Appendices S1 and S2). We gathered all pollen information from those palynological studies. The uppermost sediment sample (the sediment-water interface of a lake sediment core) was considered representative of the modern pollen percentage. The diagrams started in age zero representing the current age. The paleoecological sites are well distributed across the Amazonian lowland rainforest (Figure S3). As the pollen of Moraceae and Urticaceae are difficult to reliably distinguish (Burn \& Mayle, 2008), the percentage of pollen of both families obtained in the diagrams were pooled (Appendix S1).

\subsection{Data analysis}

We fitted a linear model to test if the core-top (modern) pollen percentages of Moraceae and Urticaceae, gathered from the pollen diagrams of the Amazonian paleoecological sites, correlated well with the relative abundance of both families in the modern vegetation surrounding these paleoecological sites. We statistically validated species' distribution models, using the receiver operating characteristic (ROC), testing which of the models had an observed value for the area under the ROC curve (AUC) significantly different from a random expectation, using bias corrected null-models (Raes \& ter Steege, 2007). We produced 99 nullmodels for each species, where the $n$ records (same number of $n$ records of the species tested) were drawn randomly without replacement using the same spatial grid of the environmental layers. If the species' observed AUC ranked above the upper one-sided 95\% confidence interval of the AUC values of the null-models (above the $95^{\text {th }}$ higher AUC values) then its modelled distribution was considered significant, with $<5 \%$ chance that a random set of $n$ records could produce an equally good model. We then excluded all species with models not significantly different from their null-models. We produced two models for each species: 'current climate' and 'Mid Holocene'. For the Mid Holocene we considered only grid cells predicted by all IPPC5 GCMs. To estimate the environmental suitability for Moraceae and Urticaceae we averaged the models of the top 20 most dominant species of each family. The top 20 most dominant species were selected by following ter Steege et al. (2015). Those species represent most of the individuals of the families (more than $50 \%$ for both families). We also modelled Moraceae and Urticaceae richness and quantified its increase between the Mid Holocene and current climate. To assess the richness of the families, we transformed the modelled potential distribution as predicted by MaxEnt into binary maps using the "10 percentile training 
presence threshold". This threshold rejects $10 \%$ of the records in the lowest predicted values of the modelled potential distribution, and tends to preserve high prediction rates as sample sizes are reduced (Pearson et al., 2007), and that may be the case for some species we modelled which have only a few records. Then, we stacked those binary maps for all species to assess species richness (Gomes et al., 2019). All calculations and analyses were performed with R v.3.4.3 (R Core Team, 2019), including the R 'gstat' v.1.1-6 (Pebesma \& Graeler, 2014), 'maptools' v.0.9-2 (Roger Bivand \& Lewin-Koh, 2017), 'rgdal' v.1.2-16 (R. Bivand et al., 2014), 'rgeos' v.0.3-26 (Roger Bivand \& Rundel, 2017), 'rJava' v.0.9-9 (Urbanek, 2017) and 'speciesgeocodeR' v.1.0-4 (Zizka \& Antonelli, 2015).

\section{RESULTS}

\subsection{Modelled species, current environmental suitability and species richness}

We analysed data for 216 tree species of Moraceae and Urticaceae with records available in GBIF. A total of 13,926 records (mean 64, minimum of 2 and maximum of 456 records) were used and 199 species had (i) sufficient available records in GBIF ( $>5$ ), and a total 176 also had (ii) modelled distributions that were significantly different from a random expectation tested using null models ( $>95^{\text {th }}$ null model) (Appendix S3 and S4). Those species were used to model environmental suitability and species richness. The 20 most abundant tree species of Moraceae and Urticaceae used to model the mean environmental suitability of the families included 13 species of Moraceae and 7 species of Urticaceae (Appendix S5). Moraceae species are generally more abundant than those of Urticaceae; e.g. the 20 most abundant Moraceae species are roughly $60 \%$ more abundant than the 20 most abundant Urticaceae species in Amazonia. Mean species richness for past and current climate was estimated using the 176 species with sufficient number of records and significant modelled distributions, 111 of which are from Moraceae and 65 of which are from Urticaceae. The major emergent patterns are: (i) current environmental suitability and species richness are higher in north-western, central Amazonia and in a narrow band in the Guiana Shield (Appendix S6, Figure 1a,b and Figure $2 a, b)$, (ii) both families show roughly the same spatial pattern for environmental suitability and species richness (Appendix S6, Figure S4 and S5).

\subsection{Species current relative abundance and pollen assemblages}

The relative abundance models were based on all individuals of Moraceae and Urticaceae. The fit of the models against the observed abundance resulted in $a R^{2}=35.7$ for Moraceae and Urticaceae, $R^{2}=44 \%$ for Moraceae and $R^{2}=11.8$ for Urticaceae. The families accounted for on average $7 \%$ of all individuals in the forest, but were distinctly more dominant in south-western Amazonia (13\%, Appendix S6, Figure 3), followed by southern Amazonia (9\%) and northwestern Amazonia (7\%). The lowest relative abundance was found in the Guyana shield (3\%). This contrasts strongly with the current environment suitability and species richness patterns (Figure $1 \mathrm{a}, \mathrm{b}$ ). Moraceae, the most common family of the two, drives the overall spatial pattern, and shows the highest abundance in southern and south-western, ranging between 0 - 
$11 \%$ (mean of 5\%) throughout Amazonia; whereas Urticaeae ranges from 0.1-6.3\% (mean of 2.0\%) (Figure $56 a)$. Urticaceae is more evenly spread across Amazonia, with three notable peaks in abundance in parts of eastern, south-western and north-western Amazonia (Figure S6b).

We found that the mean percentage abundance of Moraceae and Urticaceae pollen was highest at sites located in southern/south-western Amazonia (39\%, Appendix S1), although also high in north-western Amazonia (19\%). Pollen percentages of Moraceae and Urticaceae in the modern pollen assemblages of the surface-sediment lake cores were a good proxy for their pooled relative abundance in the modern vegetation, showing a significant and positive correlation $\left(R^{2}=52 \%, P<0.05\right.$; Figure 4; Appendix S1). The modern pollen percentages of Moraceae and Urticaceae were driven mainly by the relative abundance of Moraceae $\left(R^{2}=\right.$ $56 \%, P<0.05)$ and much less by the relative abundance of Urticaceae which showed only a very weak correlation $\left(R^{2}=11 \%, P<0.05\right)$ (Figure $S 7 a, b$ and Appendix S1).

\subsection{Species environmental suitability during the Mid-Late Holocene}

The mean environmental suitability for Moraceae and Urticaceae species increased over all of Amazonia during the Mid-Late Holocene (6.5\%). Particularly, it increased in the Guiana Shield (7\%), eastern Amazonia (16\%), central Amazonia (5.8\%), in the rainforest-savanna boundaries in south-western (4.4\%) and in southern Amazonia (13.2\%), but decreased in north-western Amazonia (-3.5\%) (Appendix S6, Figure S8). Although the mean variation was low, it ranged widely between -34 and $68 \%$ considering all grid cells. The average increase for Moraceae species over all of Amazonia was $8.5 \%$, for the Guiana Shield it was $10 \%$, followed by eastern (18\%), south-western (7\%), southern Amazonia (15\%) and central Amazonia (7\%). Mean environmental suitability decreased in north-western Amazonia (-3\%) (Appendix S6, Figure S9). The average increase for Urticaceae species over all of Amazonia was 9.7\%, and was higher in eastern Amazonia (30\%), in the Guiana Shield (13\%) and southern Amazonia (13\%). It was lower in central (8.9\%) and south-western Amazonia (3.7\%). In north-western Amazonia it showed a low decrease (-0.6\%) (Appendix S6, Figure S9b).

\subsection{Modelled species richness during the Mid-Late Holocene}

The mean modelled species richness for 0.5-degree grid cells strongly increased throughout Amazonia during the Mid-Late Holocene (122\%). Mean modelled species richness was lower in eastern Amazonia (7.8\%), but this region showed the highest increase in mean modelled species richness (397\%) (Appendix S6, Figure $1 \mathrm{~b}$ and $2 \mathrm{~b}$ ). Some areas with no modelled presence of Moraceae and Urticaceae in the past showed a mean increase of 14 species during the Mid-Late Holocene. Those areas were located in the Guiana Shield and eastern Amazonia. North-western Amazonia showed the highest mean modelled species richness (99 species, Appendix S5), but the lowest increase of all regions (14\%). The mean modelled species richness was lowest in southern, south-western and eastern Amazonia. For Moraceae, the mean 
increase in modelled species richness was higher in the Guiana Shield and central Amazonia (Appendix S6, Figure S10a). Urticaceae followed a similar modelled species richness pattern as Moraceae but also showed peaks in north-western and central Amazonia (Appendix S6, Figure S10b).

\section{DISCUSSION}

One of the aims of our study was to determine whether environmental suitability increased during the Mid-Late Holocene, influencing the distribution of Moraceae and Urticaceae in Amazonia in response to long-term climate change. Under current climatic conditions, both families are widespread across Amazonia. Taxa with wide ranges, such as Moraceae and Urticaceae, are widespread across the precipitation gradient of the region, indicating that some of their constituent species have high tolerance to water-stress. Species distribution in Amazonia is strongly associated with precipitation (Esquivel-Muelbert et al., 2017). The environmental suitability and the modelled richness were higher in north-western and central Amazonia, but lower in southern, south-western and eastern Amazonia. Species richness was much lower in southern, south-western and eastern Amazonia, especially at the ecotonal boundary between the rainforest and the Cerrado savannas.

Ter Steege et al. (2003) mapped Amazonian tree $\alpha$-diversity and also found a similar pattern, where diversity was higher in north-western and central Amazonia. They hypothesized that the low diversity in Bolivian and Brazilian ecotonal rainforests reflected their recent expansion within the last 2-3 millennia, as shown by Mayle et al. (2000). This would imply that these young rainforests are still undergoing succession and are still accumulating species (ter Steege et al., 2000), and that the high abundance of Moraceae and Urticaceae in these ecotonal rainforests, where environmental suitability was lower compared to other regions, likely reflects the rapid dispersal ability and fast growth rates of some of their species. The high species richness we found in western Amazonia has also been attributed to stable climatic conditions in the region since the last glacial period (Cheng et al., 2013), as well as a shorter dry season (ter Steege et al., 2006, 2003) and the wetter and less seasonal climate (Hoorn et al., 2010).

Environmental suitability and species richness were also higher in a narrow band in the Guiana Shield. The relative abundance of both Moraceae and Urticaceae was very low in that area. Both modelled species richness and mean environmental suitability of Moraceae and Urticaceae contrasted strongly with their relative abundance in the forest (Figure $1 \mathrm{a}, \mathrm{b}$ and Figure 3). The relative abundance was highest in south-western Amazonia and lower in northwest and central Amazonia. For Moraceae this pattern was more pronounced. This may reflect the influence of other factors besides abundance on species distribution, such as biotic interactions which may dissociate a species' observed distribution from its potential 
distribution as predicted by environmental suitability (Anderson \& Martínez-Meyer, 2004; Elith et al., 2011). Ter Steege et al. (2003) suggested that tree species diversity in the Guiana Shield may be linked to the small size of this area in comparison with the much larger tract of forest dominating the Amazon watershed. The Guianas also hold very poor soils, and low forest dynamics, which together may restrict the environmental conditions needed by fast-growing groups of species, such as Moraceae, to become dominant (Grau et al., 2017; van der Sande et al., 2018).

The mean environmental suitability for Moraceae and Urticaceae increased in the Guiana Shield, eastern, south-western and southern Amazonia during the Mid-Late Holocene (Figure S8) but this is not reflected in a high abundance. The Guiana Shield is dominated by tree species with large seeds and dense wood, indicative of low forest dynamics (ter Steege et al., 2006). While environmental suitability increased the low dynamics may hamper the establishment of fast-growing Moraceae and small-seeded pioneer species of Urticaceae that germinate fast. The observed increase in southern and south-western Amazonia along the ecotonal boundaries between the rainforest and the Cerrado savannas corroborates the interpretation by Mayle et al. (2000) that Moraceae and Urticaceae species may have tracked climate change southward in the last three millennia. Species richness increased mostly in regions where diversity was already high, and climatic conditions were stable, such as western and central Amazonia.

We measured environmental suitability using MaxEnt. Modelling environmental suitability based on a single SDM method may be considered a limitation of our approach. Analyses have shown divergences between different methods, especially when projecting the distributions of species under climate change scenarios (Pearson et al., 2006; Thuiller, 2004). This makes the choice of the appropriate model more difficult for most analyses. Previous studies used the ensembles of different methods combining their measures of environmental suitability and avoiding such difficulty (Diniz-Filho et al., 2009; Thuiller et al., 2011). Despite that, previous studies have successfully used MaxEnt to model environmental suitability under climate change scenarios in Amazonia (Bush \& McMichael, 2016; Gomes et al., 2019). Gomes et al. (2018) compared MaxEnt's models with a nearly independent plot dataset of Amazonian tree species and their results showed that MaxEnt's ability in predicting species presence was very high (mean sensitivity close to 90\%). Also, Maxent is little sensitive to small sample sizes (Wisz et al., 2008). This is particularly important when modelling species distribution in an area as vast and data-scarce as Amazonia, where roughly $30 \%$ of the tree species are expected to have a population size smaller than 1000 individuals (ter Steege et al., 2013). In our dataset of Moraceae and Urticaceae $22 \%$ of the species occurred with less than 10 records (Appendix S3).

At an Amazon basin-wide scale we found that abundance of both families in lake surfacesediment pollen assemblages was well correlated with their pooled relative abundances in the 
vegetation (Figure 3). The abundance of Moraceae and Urticaceae in modern pollen records therefore serves as a good proxy for the relative abundance of these families in the modern vegetation, especially with respect to Moraceae, contributing to the assumptions that most of the pollen records may be attributed to this family. We found that, although Moraceae and Urticaceae pollen registered in modern pollen assemblages throughout Amazonia, it was most abundant in south-western, north-western and southern regions of the basin.

The pollen of Moraceae/Urticaceae is well-represented in Amazonian fossil records, but is difficult to reliably differentiate, at both family and genus level (Burn \& Mayle, 2008). In our analyses, we therefore pooled the pollen of Moraceae and Urticaceae. Based on comparison with floristic inventories, most palynologists attribute the majority of the Moraceae/Urticaceae type pollen in their assemblages to the Moraceae family (Burbridge et al., 2004; Mayle et al., 2000). Our results support this assumption, as the relationship we found between the relative abundance of Urticaceae tree species and pooled pollen of Moraceae and Urticaceae was very weak. Burn et al. (2010) showed that the pollen rain composition from artificial pollen traps was similar to that of lake surface sediments in both moist forests of the Madeira-Tapajós ecoregion and the savanna wetlands of the Beni ecoregion. Gosling et al.(2009) compared modern pollen trap data with floristic inventories of ecological plots to determine pollen-vegetation relationships for rainforest, dry forest, and savanna ecosystems in northeast Bolivia. While their results showed that no taxon could be used as an indicator of tropical rainforest, they did confirm that high abundance of Moraceae pollen (over $40 \%$ ) was a reliable indicator for this vegetation type. We therefore conclude that the stratigraphic changes in abundance of Moraceae/Urticaceae type pollen in sediment cores reflects past changes in abundance of tree species of these families in the vegetation through time.

In our analyses, the Moraceae/Urticaceae pollen was present in sediment cores spanning the Mid-Late Holocene in all Amazonian regions (Appendix S1). There is a clear trend of rising Moraceae/Urticaceae pollen percentages through the Mid-Late Holocene, especially in ecotonal southern and northern Amazonia: Lagunas Bella Vista, Chaplin, and Oricore (Carson et al., 2014; Mayle et al., 2000) in northeastern Bolivia, Loma Linda in eastern Colombia (Behling \& Hooghiemstra, 2000), middle Caquetá river basin (Colombia) (Behling et al., 1999), Fazenda Cigana and Terra indígena Aningal (Roraima, northern Brazil) (Da Silva Meneses et al., 2013), and lakes Marcio and Tapera in Amapá (northern Brazil) (De Toledo \& Bush, 2007), and much further increased in Amazonian forest close to Pantanal (Whitney et al., 2011) and in Lago do Saci (Fontes et al., 2017). The palynological richness of Moraceae pollen also increased in Bolivian dry forests $600 \mathrm{~km}$ southward of Amazonia indicating that their flora was also assembled during Late Holocene influenced by changes in the precipitation regime (Whitney et al., 2014). In Mid-Late Holocene assemblages of Moraceae and Urticaceae pollen were registered in sediment cores in all Amazonian regions, consistent with our modelling results showing presence of Moraceae species throughout this time period across Amazonia. Sites 
with pollen evidence for continuous forest cover through the Holocene occur in eastern, western, and central Amazonia (Appendix S1). Moraceae/Urticaceae pollen was present in cores from all these sites, with high abundance in western Amazonia and much lower, but constant, abundance in the Guyana Shield sites, consistent with floristic inventories of 1 ha ecological plots across the basin.

We have shown that mean environmental suitability for Moraceae and Urticaceae tree species increased during the Mid-Late Holocene throughout Amazonia, especially at the ecotonal rainforest-savanna boundaries toward the northern and southern margins of the basin. Our modelling results build upon and strengthen paleoenvironmental interpretations from earlier fossil pollen studies (e.g. Mayle et al., 2000); i.e. that the long-term trend of rising precipitation through the Mid-Late Holocene increased the environmental suitability for Amazonian tree species in the Moraceae and Urticaceae families, thereby facilitating their range expansions at ecotonal boundaries.

Our results imply that, under a future warmer, drier Amazonia, as predicted under most GCMs (Hijmans et al., 2005), it is likely that the late Holocene range expansion of Moraceae, Urticaceae and many other taxa will be reversed over the $21^{\text {st }}$ century due to increased moisture stress, leading to large forest and diversity losses, especially in ecotonal areas of Amazonia (Gomes et al., 2019; Mayle et al., 2007). 


\section{LEGEND TO FIGURES}

Figure 1. Current mean modelled environmental suitability and modelled species richness for Moraceae and Urticaceae. (a), Map for current mean modelled environmental suitability. (b), Map for current modelled species richness. Circles in green, Numbers of species collections by 0.5-degree cell (a); Number of single species collected by 0.5-degree cell (b). Gray line, approximate boundary of Amazonian rainforest. Maps created with custom R script ( $R$ Core Team, 2019). Base map source (country.shp, rivers.shp): ESRI (http://www.esri.com/data/basemaps, @ Esri, DeLorme Publishing Company).

Figure 2. Percentage of increase in mean modelled environmental suitability and species richness during the Mid-Late Holocene (between current climate and Mid Holocene climate conditions, last 6,000 yr BP). (a), increase in mean modelled environmental suitability. (b), Increase in mean modelled species richness. Graph created with custom R script (R Core Team, 2019).

Figure 3. Current modelled relative abundance for Moraceae and Urticaceae. Circles in green, relative abundance of the families on the ATDN plots. Circles in yellow, percentage of modern pollen assemblages in the core's sediment of the paleoecological sites corresponding to the values in Appendix S1. Gray line, Amazonian rainforest. Maps created with custom R script (R Core Team, 2019). Base map source (country.shp, rivers.shp): ESRI (http://www.esri.com/data/basemaps, @ Esri, DeLorme Publishing Company).

Figure 4. Relationship between predicted relative abundance and modern pollen assemblages of Moraceae and Urticaceae (Appendix S1). The assemblages of pollen were gathered from the pollen percentage in the diagrams of 46 Amazonian paleoecological sites. $R^{2}$ $=52 \%$. 
FIGURES

Figure 1
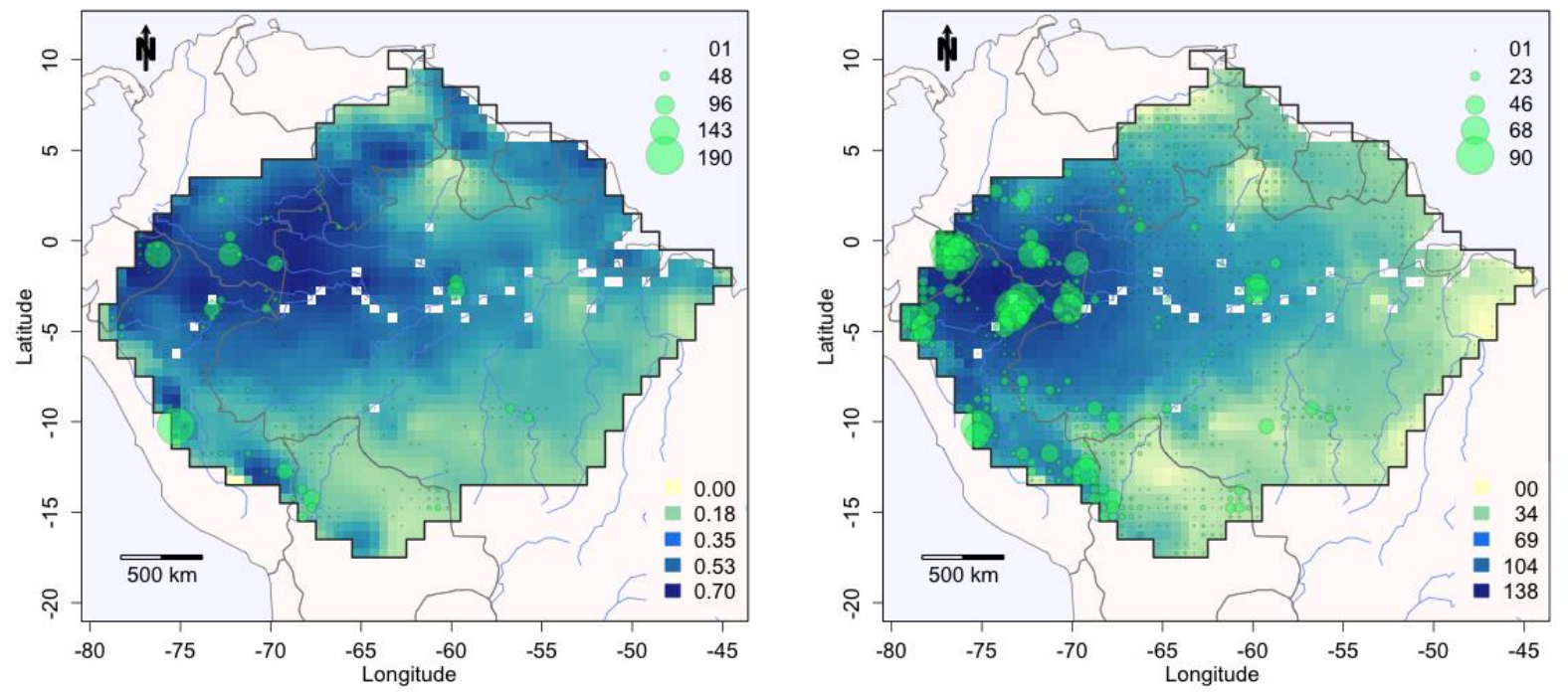
Figure 2
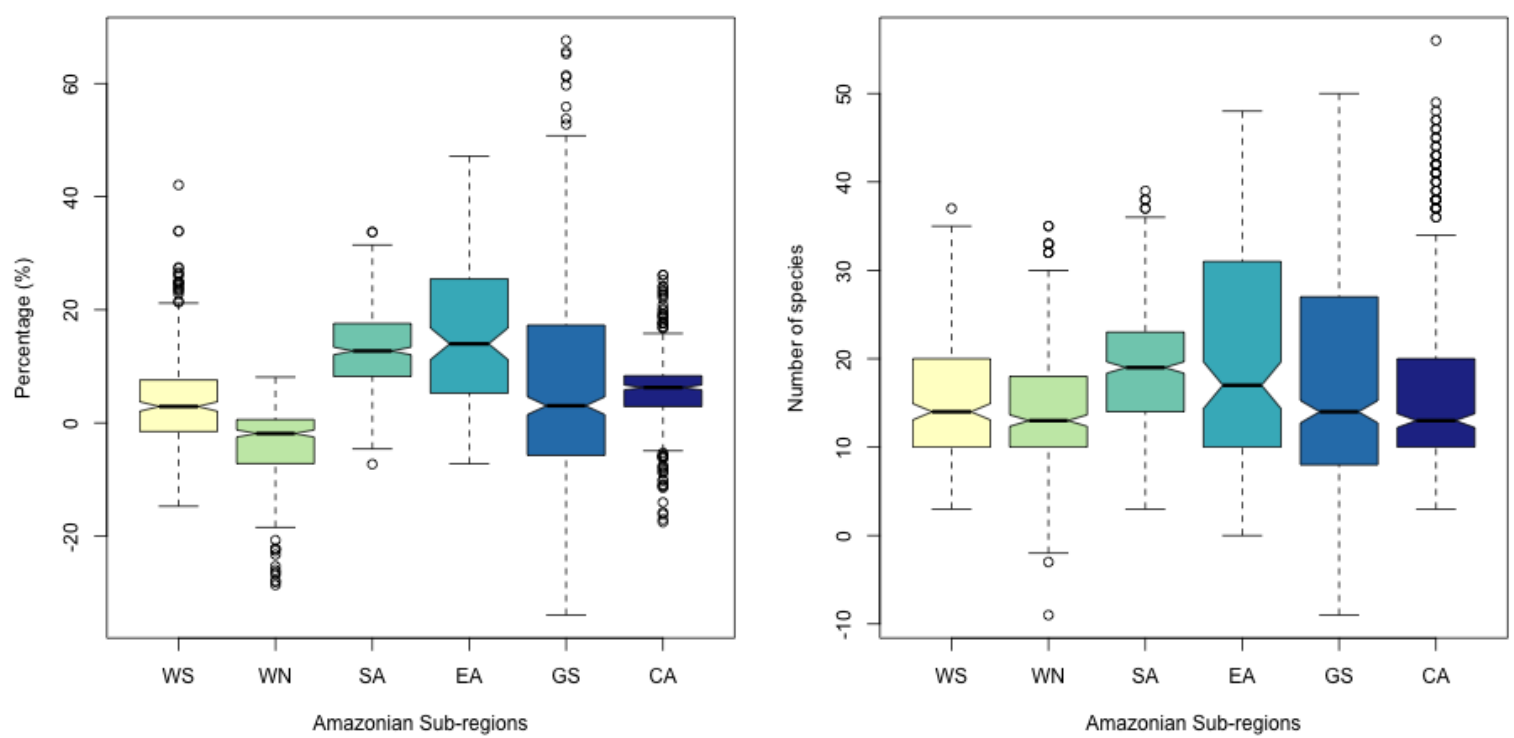
Figure 3

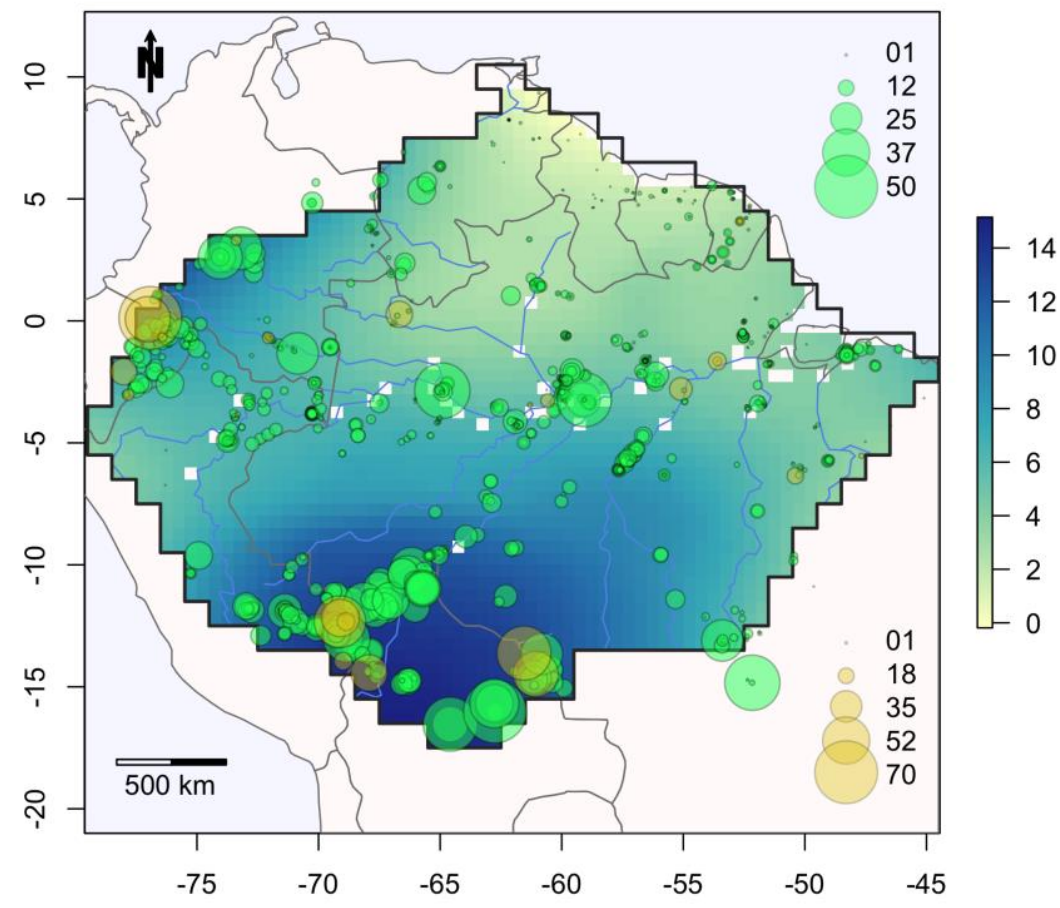


Figure 4

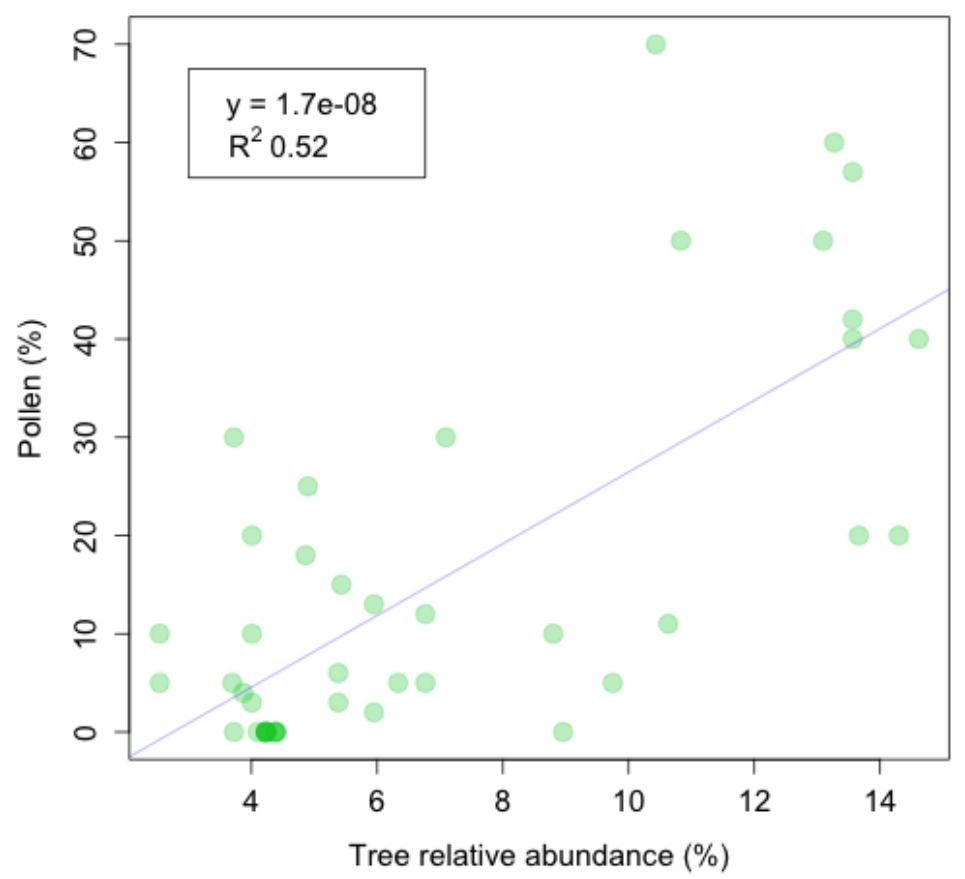




\section{ACKNOWLEDGEMENTS}

We thank the Amazon Tree Diversity Network (http://atdn.myspecies.info/) for the use of unpublished plot abundance data of Moraceae and Urticaceae and two anonymous reviewers for helpful comments on the manuscript. V. H. F. Gomes, H. ter Steege and R. P. Salomão were supported by grant 407232/2013-3 - PVE - MEC/MCTI/CAPES/CNPq/FAPs. R. P. Salomão is also supported by Programa Professor Visitante Nacional Sênior na Amazônia - CAPES. I. C. G. Vieira is supported by grant 308778/2017-0 - CNPq. This study was financed in part by the Coordenação de Aperfeiçoamento de Pessoal Nível Superior - Brazil (CAPES) - Finance Code 001.

\section{DATA AVAILABILITY}

All data used can be freely downloaded from GBIF (http://www. gbif.org) and WorldClim (http://www.worldclim.org). The occurrence dataset is available at the Dryad Digital Repository (https:// doi.org/10.5061/dryad.m37pvmczg). A full list of species used can be found in Appendix S4

\section{ORCID IDs}

Vitor H. F. Gomes https://orcid.org/0000-0002-3855-5584

Francis E. Mayle https://orcid.org/0000-0001-9208-0519

William D. Gosling https://orcid.org/0000-0001-9903-8401

Ima C. G. Vieira https://orcid.org/0000-0003-1233-318X

Rafael P. Salomão https://orcid.org/0000-0003-0947-0132

Hans ter Steege https://orcid.org/0000-0002-8738-2659 


\section{REFERENCES}

Aguirre-Gutiérrez, J., Carvalheiro, L.G., Polce, C., van Loon, E.E., Raes, N., Reemer, M., \& Biesmeijer, J.C. (2013). Fit-for-purpose: species distribution model performance depends on evaluation criteria - Dutch hoverflies as a case study. PLOS ONE, 8(5), e63708.

Anderson, R.P., \& Martínez-Meyer, E. (2004). Modeling species' geographic distributions for preliminary conservation assessments: an implementation with the spiny pocket mice (Heteromys) of Ecuador. Biological Conservation, 116(2), 167-179.

Behling, H., Carlos Berrio, J., \& Hooghiemstra, H. (1999). Late Quaternary pollen records from the middle Caquetá river basin in central Colombian Amazon. Palaeogeography, Palaeoclimatology, Palaeoecology, 145(1), 193-213.

Behling, H., \& Hooghiemstra, H. (2000). Holocene Amazon rainforest-savanna dynamics and climatic implications: High-resolution pollen record from Laguna Loma Linda in eastern Colombia. Journal of Quaternary Science, 15(7), 687-695.

Bivand, R., Keitt, T., \& Rowlingson, B. (2014). rgdal: bindings for the geospatial data abstraction library v.0.8-16. https://cran.r-project.org/package=rgdal.

Bivand, Roger, \& Lewin-Koh, N. (2017). maptools: tools for reading and handling spatial objects v.0.9-2. https://cran.r-project.org/package=maptools.

Bivand, Roger, \& Rundel, C. (2017). rgeos: interface to geometry engine - open source v.0.3-26. https://cran.r-project.org/package=rgeos.

Boucher-Lalonde, V., Morin, A., \& Currie, D.J. (2012). How are tree species distributed in climatic space? A simple and general pattern. Global Ecology and Biogeography, 21(12), 11571166.

Bueno, M.L., Pennington, R.T., Dexter, K.G., Kamino, L.H.Y., Pontara, V., Neves, D.M., ...de Oliveira-Filho, A.T. (2017). Effects of Quaternary climatic fluctuations on the distribution of Neotropical savanna tree species. Ecography, 40(3), 403-414.

Burbridge, R.E., Mayle, F.E., \& Killeen, T.J. (2004). Fifty-thousand-year vegetation and climate history of Noel Kempff Mercado National Park, Bolivian Amazon. Quaternary Research, 61(2), 215-230.

Burn, M.J., \& Mayle, F.E. (2008). Palynological differentiation between genera of the Moraceae family and implications for Amazonian palaeoecology. Review of Palaeobotany and Palynology, 149(3-4), 187-201.

Burn, M.J., Mayle, F.E., \& Killeen, T.J. (2010). Pollen-based differentiation of Amazonian rainforest communities and implications for lowland palaeoecology in tropical South America. Palaeogeography, Palaeoclimatology, Palaeoecology, 295(1-2), 1-18.

Bush, M.B., \& McMichael, C.N.H. (2016). Holocene variability of an Amazonian hyperdominant. Journal of Ecology, 104(5), 1370-1378. 
Carson, J.F., Whitney, B.S., Mayle, F.E., Iriarte, J., Prümers, H., Soto, J.D., \& Watling, J. (2014). Environmental impact of geometric earthwork construction in pre-Columbian Amazonia. Proceedings of the National Academy of Sciences, 111(29), 10497-10502.

Cheng, H., Sinha, A., Cruz, F.W., Wang, X., Edwards, R.L., d'Horta, F.M., ... Auler, A.S. (2013). Climate change patterns in Amazonia and biodiversity. Nature Communications, 4, 1411.

Clark, P.U., Shakun, J.D., Baker, P.A., Bartlein, P.J., Brewer, S., Brook, E.J., ... Williams, J.W. (2012). Global climate evolution during the last deglaciation. Proceedings of the National Academy of Sciences, 109(19), 1134-1142.

Costa, P.C., Lorenz-Lemke, A.P., Furini, P.R., Honorio Coronado, E.N., Kjellberg, F., \& Pereira, R.A.S. (2017). The phylogeography of two disjunct Neotropical Ficus (Moraceae) species reveals contrasted histories between the Amazon and the Atlantic Forests. Botanical Journal of the Linnean Society, 185(2), 272-289.

Da Silva Meneses, M.E.N., Da Costa, M.L., \& Behling, H. (2013). Late Holocene vegetation and fire dynamics from a savanna-forest ecotone in Roraima state, northern Brazilian Amazon. Journal of South American Earth Sciences, 42, 17-26.

De Toledo, M.B., \& Bush, M.B. (2007). A mid-Holocene environmental change in Amazonian savannas.Journal of Biogeography, 34(8), 1313-1326.

Diniz-Filho, J.A.F., Bini, L., Rangel, T., Loyola, R.D., Hof, C., Nogués-Bravo, D., \& Araújo, M.B. (2009). Partitioning and mapping uncertainties in ensembles of forecasts of species turnover under climate change. Ecography, 32(6), 897-906.

Dormann, C.F., Elith, J., Bacher, S., Buchmann, C., Carl, G., Carré, G., ...Lautenbach, S. (2013). Collinearity: a review of methods to deal with it and a simulation study evaluating their performance. Ecography, 36(1), 27-46.

Elith, J., \& Graham, C.H. (2009). Do they? How do they? Why do they differ? On finding reasons for differing performances of species distribution models. Ecography, 32(1), 66-77.

Elith, J., H.Graham, C., P.Anderson, R., Dudík, M., Ferrier, S., Guisan, A., ... E.Zimmermann, N. (2006). Novel methods improve prediction of species' distributions from occurrence data. Ecography, 29(2), 129-151.

Elith, J., Phillips, S.J., Hastie, T., Dudík, M., Chee, Y.E., \& Yates, C.J. (2011). A statistical explanation of MaxEnt for ecologists. Diversity and Distributions, 17(1), 43-57.

Esquivel-Muelbert, A., Baker, T.R., Dexter, K.G., Lewis, S.L., ter Steege, H., Lopez-Gonzalez, G., ... Phillips, O.L. (2016). Seasonal drought limits tree species across the Neotropics. Ecography, April, 1-12.

Fontes, D., Cordeiro, R.C., Martins, G.S., Behling, H., Turcq, B., Sifeddine, A., ... Rodrigues, R.A. (2017). Paleoenvironmental dynamics in South Amazonia, Brazil, during the last 35,000 years inferred from pollen and geochemical records of Lago do Saci. Quaternary Science Reviews, $173,161-180$. 
Gastón, A., \& García-Viñas, J.I. (2011). Modelling species distributions with penalised logistic regressions: A comparison with maximum entropy models. Ecological Modelling, 222(13), 2037-2041.

Giorgetta, M.A., Jungclaus, J., Reick, C.H., Legutke, S., Bader, J., Böttinger, M., ... Stevens, B. (2013). Climate and carbon cycle changes from 1850 to 2100 in MPI-ESM simulations for the Coupled Model Intercomparison Project phase 5. Journal of Advances in Modeling Earth Systems, 5(3), 572-597.

Gomes, V.H.F., IJff, S.D., Raes, N., Amaral, I.L., Salomão, R.P., de Souza Coelho, L ... ter Steege, H. (2018). Species Distribution Modelling: Contrasting presence-only models with plot abundance data. Scientific Reports, 8(1), 1003.

Gomes, V.H.F., Vieira, I.C.G., Salomão, R.P., \& ter Steege, H. (2019). Amazonian tree species threatened by deforestation and climate change. Nature Climate Change, 9(7), 547.

Gosling, W.D., Mayle, F.E., Tate, N.J., \& Killeen, T.J. (2005). Modern pollen-rain characteristics of tall terra firme moist evergreen forest, southern Amazonia. Quaternary Research, 64(3), 284-297.

Gosling, W.D., Mayle, F.E., Tate, N.J., \& Killeen, T.J. (2009). Differentiation between Neotropical rainforest, dry forest, and savannah ecosystems by their modern pollen spectra and implications for the fossil pollen record. Review of Palaeobotany and Palynology, 153(12), 70-85.

Grau, O., Peñuelas, J., Ferry, B., Freycon, V., Blanc, L., Desprez, M., ...Hérault, B. (2017). Nutrient-cycling mechanisms other than the direct absorption from soil may control forest structure and dynamics in poor Amazonian soils. Scientific Reports, 7, 45017.

Hijmans, R.J., Cameron, S.E., Parra, J.L., Jones, P.G., \& Jarvis, A. (2005). Very high resolution interpolated climate surfaces for global land areas. International Journal of Climatology, 25(15), 1965-1978.

Hijmans, Robert J. (2017). raster: Geographic Data Analysis and Modeling v.2.9-23. https://cran.r-project.org/package=raster.

Hijmans, Robert J, Phillips, S., Leathwick, J., \& Elith, J. (2017). dismo: species distribution modeling v.1.1-4. https://cran.r-project.org/package=dismo.

Hoorn, C., Wesselingh, F.P., ter Steege, H., Bermudez, M.A., Mora, A., Sevink, J., ...Antonelli, A. (2010). Amazonia through time: Andean uplift, climate change, landscape evolution, and biodiversity. Science, 330(6006), 927-931.

IUCN (2019). Guidelines for Using the IUCN Red List Categories and Criteria v.14. Prepared by the Standards and Petitions Subcommittee.

https://www.iucnredlist.org/resources/redlistguidelines. 
Jiménez-Valverde, A., Lobo, J.M., \& Hortal, J. (2008). Not as good as they seem: The importance of concepts in species distribution modelling. Diversity and Distributions, 14(6), 885-890.

Jones, C.D., Hughes, J.K., Bellouin, N., Hardiman, S.C., Jones, G.S., Knight, J., ... Zerroukat, M. (2011). The HadGEM2-ES implementation of CMIP5 centennial simulations. Geoscientific Model Development, 4(3), 543-570.

Jones, H.T., Mayle, F.E., Pennington, R.T., \& Killeen, T.J. (2011). Characterisation of Bolivian savanna ecosystems by their modern pollen rain and implications for fossil pollen records. Review of Palaeobotany and Palynology, 164(3-4), 223-237.

Latrubesse, E.M., \& Ramonell, C.G. (1994). A climatic model for southwestern Amazonia in Last Glacial times. Quaternary International, 21, 163-169.

Ledo, R.M.D., \& Colli, G.R. (2017). The historical connections between the Amazon and the Atlantic Forest revisited. Journal of Biogeography, 44(11), 2551-2563.

Martin, L., Bertaux, J., Correge, T., Ledru, M.P., Mourguiart, P., Sifeddine, A., ...Turcq, B. (1997). Astronomical forcing of contrasting rainfall changes in tropical South America between 12,400 and 8800 cal yr BP. Quaternary Research, 47(1), 117-122.

Maslin, M.a, \& Burns, S.J. (2000). Reconstruction of the Amazon Basin effective moisture availability over the past 14,000 years. Science, 290(5500), 2285-2287.

Mayle, F.E., \& Beerling, D.J. (2004). Late Quaternary changes in Amazonian ecosystems and their implications for global carbon cycling. Palaeogeography, Palaeoclimatology, Palaeoecology, 214(1-2), 11-25.

Mayle, F.E., Burbridge, R., \& Killeen, T.J. (2000). Millennial-scale dynamics of southern Amazonian rain forests. Science, 290(5500), 2291-2294.

Mayle, F.E., Langstroth, R.P., Fisher, R.A., \& Meir, P. (2007). Long-term forest-savannah dynamics in the Bolivian Amazon: implications for conservation. Philosophical Transactions of the Royal Society B: Biological Sciences, 362(1478), 291-307.

Merow, C., Smith, M.J., \& Silander, J.A. (2013). A practical guide to MaxEnt for modeling species' distributions: What it does, and why inputs and settings matter. Ecography, 36(10), 1058-1069.

O’Donnell, M.S., \& Ignizio, D.A. (2012). Bioclimatic predictors for supporting ecological applications in the conterminous United States. US Geological Survey Data Series, 691(10).

Pearson, R.G., Raxworthy, C.J., Nakamura, M., \& Townsend Peterson, A. (2007). Predicting species distributions from small numbers of occurrence records: a test case using cryptic geckos in Madagascar. Journal of Biogeography, 34(1), 102-117.

Pearson, R.G., Thuiller, W., Araújo, M.B., Martinez-Meyer, E., Brotons, L., McClean, C., ...Lees, D.C. (2006). Model-based uncertainty in species range prediction. Journal of Biogeography, 33(10), 1704-1711. 
Pebesma, E., \& Graeler, B. (2014). gstat: spatial and spatio-temporal geostatistical modelling, prediction and simulation v.1.0-19. http://cran.r-project.org/package=gstat.

Phillips, S.J., \& Dudík, M. (2008). Modeling of species distributions with Maxent: New extensions and a comprehensive evaluation. Ecography, 31(2), 161-175.

Phillips, Steven J., Anderson, R.P., \& Schapire, R.E. (2006). Maximum entropy modeling of species geographic distributions. Ecological Modelling, 190(3-4), 231-259.

Quesada, C.A., Lloyd, J., Anderson, L.O., Fyllas, N.M., Schwarz, M., \& Czimczik, C.I. (2011). Soils of Amazonia with particular reference to the RAINFOR sites. Biogeosciences, 8(6), 1415-1440.

R Core Team. (2018). R: A Language and Environment for Statistical Computing.

Raes, N. (2012). Partial versus full species distribution models. Natureza \& Conservação, 10(2), 127-138.

Raes, N., \& ter Steege, H. (2007). A null-model for significance testing of presence-only species distribution models. Ecography, 30(5), 727-736.

Reis, L.S., Guimarães, J.T.F., Souza-Filho, P.W.M., Sahoo, P.K., de Figueiredo, M.M.J.C., de Souza, E.B., \& Giannini, T.C. (2017). Environmental and vegetation changes in southeastern Amazonia during the late Pleistocene and Holocene. Quaternary International, 449, 83-105.

Smith, R., Singarayer, J., \& Mayle, F. (2018). How well do vegetation models simulate midHolocene Amazonia? EGU General Assembly Conference Abstracts, 20, 14659.

Swingedouw, D., Mignot, J., Labetoulle, S., Guilyardi, É., \& Madec, G. (2013). Initialisation and predictability of the AMOC over the last 50 years in a climate model. Climate Dynamics, 40 , 2381-2399.

Syfert, M.M., Joppa, L., Smith, M.J., Coomes, D.A., Bachman, S.P., \& Brummitt, N.A. (2014). Using species distribution models to inform IUCN Red List assessments. Biological Conservation, 177, 174-184.

Tatebe, H., Ishii, M., Mochizuki, T., Chikamoto, Y., Sakamoto, T.T., Komuro, Y., ...Kimoto, M. (2012). The initialization of the MIROC climate models with hydrographic data assimilation for decadal prediction. Journal of the Meteorological Society of Japan, 90A(0), 275-294.

ter Steege, H., \& Hammond, D.S. (2001). Character convergence, diversity, and disturbance in tropical rain forest in Guyana. Ecology, 82(11), 3197-3212.

ter Steege, H., Mota de Oliveira, S., Sabatier, D., Antonelli, A., Pitman, N., Guevara, J.E., \& Salomão, R.P. (2019). Towards a dynamic list of Amazonian tree species. Scientific Reports, 9(1), 3501.

ter Steege, H., Pitman, N.C.A., Killeen, T.J., Laurance, W.F., Peres, C.A., Guevara, J.E., ... Gamarra, L.V. (2015). Estimating the global conservation status of more than 15,000 Amazonian tree species. Science Advances, 1(10), 9-11. 
ter Steege, H., Pitman, N.C.A., Sabatier, D., Baraloto, C., Salomão, R.P., Guevara, J.E., ... Silman, M.R. (2013). Hyperdominance in the Amazonian tree flora. Science, 342(6156), 1243092.

ter Steege, H., Pitman, N.C.A, Phillips, O.L., Chave, J., Sabatier, D., Duque, A., ... Vásquez, R. (2006). Continental-scale patterns of canopy tree composition and function across Amazonia. Nature, 443(7110), 0-2.

ter Steege, H., Pitman, N., Sabatier, D., Castellanos, H., Van Der Hout, P., Daly, D.C., ... Morawetz, W. (2003). A spatial model of tree $\alpha$-diversity and tree density for the Amazon. Biodiversity and Conservation, 12(11), 2255-2277.

ter Steege, H., Sabatier, D., Castellanos, H., Van Andel, T., Duivenvoorden, J., Adalardo De Oliveira, A., ...Mori, S. (2000). An analysis of the floristic composition and diversity of Amazonian forests including those of the Guiana Shield. Journal of Tropical Ecology, 16(6), 801-828.

Thuiller, W. (2004). Patterns and uncertainties of species' range shifts under climate change. Global Change Biology, 10(12), 2020-2027.

Thuiller, W., Lavergne, S., Roquet, C., Boulangeat, I., Lafourcade, B., \& Araujo, M. (2011). Consequences of climate change on the tree of life in Europe. Nature, 470(7335), 531-534.

Urbanek, S. (2017). rJava: low-level R to Java interface v0.9-9.https://cran.rproject.org/package=rJava.

van der Sande, M.T., Arets, E.J.M.M., Peña-Claros, M., Hoosbeek, M.R., Cáceres-Siani, Y., van der Hout, P., \& Poorter, L. (2018). Soil fertility and species traits, but not diversity, drive productivity and biomass stocks in a Guyanese tropical rainforest. Functional Ecology, 32(2), 461-474.

van Proosdij, A.S.J., Sosef, M.S.M., Wieringa, J.J., \& Raes, N. (2015). Minimum required number of specimen records to develop accurate species distribution models. Ecography, 39(6), 542552.

VanDerWal, J., Shoo, L.P., Graham, C., \& Williams, S.E. (2009). Selecting pseudo-absence data for presence-only distribution modeling: how far should you stray from what you know? Ecological Modelling, 220(4), 589-594.

Vidotto, E., Carlos, L., Pessenda, R., Ribeiro, A.D.S., Freitas, H.A., \& Bendassolli, J.A. (2007). Dinâmica do ecótono floresta-campo no sul do estado do Amazonas no Holoceno, através de estudos isotópicos e fitossociológicos. Acta Amazonica, 37(3), 385-400.

Wang, X., Edwards, R.L., Auler, A.S., Cheng, H., Kong, X., Wang, Y., ... Chiang, H.-W. (2017). Hydroclimate changes across the Amazon lowlands over the past 45,000 years. Nature, 541(7636), 204.

Watanabe, S., Hajima, T., Sudo, K., Nagashima, T., Takemura, T., Okajima, H., ... Kawamiya, M. (2011). MIROC-ESM 2010: Model description and basic results of CMIP5-20c3m experiments. Geoscientific Model Development, 4(4), 845-872. 
Whitney, B.S., Mayle, F.E., Burn, M.J., Guillén, R., Chavez, E., \& Pennington, R.T. (2014). Sensitivity of Bolivian seasonally-dry tropical forest to precipitation and temperature changes over glacial-interglacial timescales. Vegetation History and Archaeobotany, 23(1), 1-14.

Whitney, B.S., Mayle, F.E., Punyasena, S.W., Fitzpatrick, K.A., Burn, M.J., Guillen, R., ... Metcalfe, S.E. (2011). A 45kyr palaeoclimate record from the lowland interior of tropical South America. Palaeogeography, Palaeoclimatology, Palaeoecology, 307(1), 177-192.

Wisz, M.S., Hijmans, R.J., Li, J., Peterson, A.T., Graham, C.H., \& Guisan, A. (2008). Effects of sample size on the performance of species distribution models. Diversity and Distributions, 14(5), 763-773.

Xiao-Ge, X., Tong-Wen, W., \& Jie, Z. (2013). Introduction of CMIP5 experiments carried out with the climate system models of Beijing climate center. Advances in Climate Change Research, 4(1), 41-49.

Yeager, S., Karspeck, A., Danabasoglu, G., Tribbia, J., \& Teng, H. (2012). A decadal prediction case study: Late twentieth-century north Atlantic Ocean heat content. Journal of Climate, 25(15), 5173-5189.

Zizka, A., \& Antonelli, A. (2015). speciesgeocodeR: An R package for linking species occurrences, user-defined regions and phylogenetic trees for biogeography, ecology and evolution. BioRxiv, 032755. http://biorxiv.org/content/early/2015/11/24/032755.abstract 


\section{BIOSKETCH}

V.H.F.G. is an environmental scientist interested in understand- ing how Amazonian tree species respond to global change.

Authors contributions: V.H.F.G. and H.t.S. conceived and de- signed the study; V.H.F.G. carried out the GBIF data collection; H.t.S. checked the species list. V.H.F.G. and H.t.S. carried out the analyses and wrote the R scripts. V.H.F.G., H.t.S., F.E.M and W.D.G. drafted the manuscript and all authors contributed edits and revisions.

\section{SUPPORTING INFORMATION}

Additional supporting information may be found online in the Supporting Information section.

How to cite this article: Gomes VHF, Mayle FE, Gosling WD, Vieira ICG, Salomão RP, ter Steege $\mathrm{H}$. Modelling the distribution of Amazonian tree species in response to long-term climate change during the Mid-Late Holocene. J Biogeogr. 2020;00:1-11.

https://doi.org/10.1111/jbi.13833 